\title{
Editorial: Gender sensitive research in adult education: Looking back and looking forward to explore what is and what is missing in the research agenda
}

\author{
Joanna Ostrouch-Kamińska \\ University of Warmia and Mazury, Poland (joanna.ostrouch@uwm.edu.pl) \\ Cristina C. Vieira \\ University of Coimbra, Portugal (vieira@fpce.uc.pt) \\ Barbara Merrill \\ University of Warwick, UK (barbara.merrill@warwick.ac.uk)
}

Despite legislation, policies and practice, and while some progress has been made in many countries, there are still no countries who have achieved a hundred per cent gender equality (Gender Equality Index, EIGE, 2019). Over the years this has included several supranational agreements and mandatory regulations signed by countries such as the Convention of the Elimination of all Forms of Discrimination against Women (CEDAW, 1979), the Platform of Beijing (1995), the Istanbul Convention (2011), and more recently the UN Sustainable Development Goals (2015), among others. The failure of these initiatives indicate that gender inequality, discrimination and prejudice suffered by women are embedded in structural unequal power relations. The ultimate goal of the 'gender mainstreaming principle' is the integration of a gender perspective into the preparation, design, implementation, monitoring and evaluation policies, regulatory measures and spending programmes (including research ones), with a view to promoting gender equality between women and men, and combating discrimination ${ }^{1}$. This is still a challenge between and within countries but as stressed by the EU Gender Equality Strategy 2020-2025': it is necessary to work together to build a 'Europe where women and men, girls and boys, in all their diversity, are equal - where they are free to pursue their chosen path in life and reach their full potential, where they have equal opportunities to thrive, and where they can equally participate in and lead our European society' (p. 19).

It is a myth to think that social evolution is a one-way movement, always in a positive direction. If we look, for example, at the use of women's rights as 'a bargaining chip' in the international negotiations between countries seeking economic aid to solve internal problems (Carvalho-Pinto \& Fleschenberg, 2019), it becomes clear the regrettable instrumentalisation of human rights and the unequal situations and voices that are given (or taken from) specific vulnerable groups. As Verloo (2007) states more than a decade 
ago that despite the European Union and the Council of Europe's efforts to set standards in relation to the member states' legal and policy choices concerning the implementation of gender mainstreaming, the engagement with feminist principles and the meaning given to gender equality vary tremendously across European nations.

Gender sensitive research in adult education shaped by feminist thinking promotes the use of the concept of gender as a grid to interpret reality and a tool - 'gender lenses' (Bem, 1993) - to identify specific areas where women and men suffer explicit and/or silent forms of inequality and discrimination across the lifespan (Ostrouch-Kamińska \& Vieira, 2016). Talking about gender - a controversial concept among feminist scholars (Ubieta, Henriques, \& Toldy, 2018) - is about uncovering structural inequalities, cultural norms and values which have imposed unequal power relations between women and men.

Feminist research developed in the 1970s importantly critiqued male sociology or 'malestream' as termed by feminists as the study of women's lives had previously been ignored and deemed unimportant. For Dorothy Smith: 'The women's movement has given us a sense of our right to have women's interests represented in sociology, rather than just receiving as authoritative the interests traditionally represented in a sociology put together by men' (1987, p. 85). Feminist research also opposed 'traditional' positivistic research by developing a humanistic and subjective approach through the use of biographical methods. Feminist research gives voice to marginalised women through the telling of their stories. Importantly feminists argued that research is political as echoed in their slogan 'the personal is political' by highlighting and challenging women's oppression in society.

Similarly, female academics in adult education across Europe, influenced by feminism, challenged the dominance of male researchers, and using largely biographical methods, highlighted the lives of women adult students in a range of adult education settings such as community education, higher education, and the labour market. Gender studies was also introduced into adult education pedagogy and was largely aimed at women students.

While in the past resistance to studying gender came from the positivist paradigm new resistances and anti-gender discourses are now emerging. Many feminists themselves turned to postmodernism and other perspectives which led to a highly theoretical and abstract approach which excluded the lives of working class women (Merrill \& Puigvert, 2001). Today researchers who study human rights' violations in general and specific gender inequalities within the framework of gender studies, feminist studies and women studies face continuous adversities and hidden obstacles to their career progression and consolidation (Vieira, 2012). The distressing neoliberal times, the tendency for the marketisation of intellectual products and the 'taken for granted' weakness of social areas of knowledge when compared to exact or natural sciences makes the scenario even more difficult for researchers who have a self-commitment with gender equality principles.

Acknowledging that 'knowledge has a situated nature' (Haraway, 1988), there are epistemological, ontological, ethical, and political implications for planning and doing research. In recent years researchers have highlighted the intersectional nature of inequalities in people's lives recognising that a person is classed, gendered, raced etc. so that being a black working class woman is different to being a white working class woman. As Skeggs asserts in her research 'The women never see themselves as just women: it is always read through class' $(1997$, p. 2).

The choices of research methodologies and the tools used for doing research must give voice to inequality and diversity experienced by women and men. As Ollagnier (2014) states when emphasising the importance of a gender sensitive approach on the 
education and training of adults, the uses of the gender lenses in doing research may open to participants - and to researchers - the possibility of access to (new) life opportunities.

\section{Papers on gender}

For this thematic issue on gender we have a range of five papers illustrating the diverse field of gender research in adult education.

The first article Beyond the trinity of gender, race and class: Exploring intersectionality in adult learning is written by Cindy Hanson and Amber Fletcher from Canada who invite us to go beyond the trinity of gender, race and class in exploring adult education. The authors claim that intersectional approaches are much more diverse than that trinity and that we need to consider the nuances of inequality and the complexities of representation and collective identities. By exploring literature in feminism, adult education, and intersectionality, the authors illustrate a gap at the core of adult education for social justice. They present two examples of national research with and by the Canadian Research Institute for the Advancement of Women to illustrate how intersectionality is understood and works in practice.

In the second paper LGBTI Sexualities \& intersectional research. Looking for inclusion beyond gender in adult learning \& education (ALE) practice we continue a discussion about intersectionality in research but in the context of LGBTI sexualities. The article is written by Portugese and Spanish researchers Rosanna Barros, Agustin Romero Lopez and Alejandro Granero Andujar who analyse the testimonies of the integration of a gender perspective beyond the dichotomy man-woman in practices of affective-sexual adult learning and education (ALE). Using the narrative literature review method, they discuss the inclusive practices described in 25 educational interventions on discriminations and oppressions among the aged when belonging to LGBTI communities. The authors found 'a small number of internationally documented experiences on affective-sexual education with the elderly and adults, a prevalence of the integrative model, as well as a little presence of the LGBTI community'. In conclusion they postulate the implementation of inclusive and egalitarian affective-sexual adult experiences in ALE.

With the next article: The new feminist frontier on community-based learning: popular feminism, online misogyny, and toxic masculinities we move to the digital environment of learning. Departing from the concept of social movement learning, Rita Basílio Simões, Inês Amaral and Sofia José Santos examine the significance of Internet feminist activism together with the surge of anti-feminist and misogynist ideas to adult education. They claim that social media brought opportunities both to provide social movement learning and empower feminism, while at the same time reveal misogynists ideas based on toxic understanding of masculinity. They perceive the online environment as a space for an ongoing battle towards deconstructing patriarchy in which adult education has an important role to play by focusing on connections between education and learning, communities of practice, and emancipatory struggles. In the fourth article we find a contribution from Germany. Lisanne Heilman discusses how quantitative large studies, such as PIACC and a positivistic approach in planning and doing research in social sciences may be excluding some people and groups from mainstream research. Concepts such as diversity and intersectionality are difficult to apply in quantitative research for uncovering the silenced 
sides of phenomena, even in adult education research. In her opinion, there is a need to develop a feminist approach to statistical methods and quantitative research and in particular a feminist approach to a careful and critical interpretation of methods and technics of data collection and analysis in adult education research.

With the next paper we move to an interesting but under-researched area in gender and adult education: informal learning in the family with a focus on Poland. The paper Gender and Polish Family Discourse in adult education: Towards family informal learning of adults is written by Joanna Ostrouch-Kamińska. In this paper Joanna Ostrouch-Kamińska is asking us to look at the family as a place where adult learning, in an informal way, occurs. For her the family should be viewed as an 'educational environment' in a 'culturally determined space'. From this perspective the family is not only a place where children learn but also adults. 'Reflexive criticism' forms the basis for family learning and this is shaped by the experiences and biographies of the family members. The focus is on dual career parents in Polish families and how gender shapes experiences and perceptions in relation to the same activities within the family so that gender sensitive research becomes important in understanding informal adult learning in the family.

\section{Open papers}

Besides the five papers which address the special edition on gender there are two open papers included in this edition. The first one from Finland focuses on informal learning from a quantitative perspective and is entitled The role of informal learning in adult literacy proficiency by Sari Sulkuren, Kari Nissinen, and Antero Malin. The article draws on secondary data from the PIAAC database focusing on adults aged $35-65$. The authors look at informal learning in both the workplace and outside the workplace and in particular reading literacies activities. They state that informal learning in the workplace is linked to occupation while outside the workplace it is associated with education, parents' education and gender and that informal literacies learning varies by social conditions and individual experiences.

For the second open paper we move to the south to Spain. It also focuses on literacy and is entitled Boosting adults' scientific literacy with experiential learning practices and is authored by Eduardo Dopico, Alba Ardura. Yousel J. Borrell, Laura Miralles and Eva Garcîa-Vázquez. The research is interdisciplinary drawing on researchers from education and biology to look at the promotion of citizen scientific literacy. An experimental learning seminar as well as a hands-on workshop were set up aimed at adult students. The programme focused on looking at DNA to 'identify unknown fish species'. The study illuminated that while adult students find scientific concepts difficult to understand they are motivated to engage with science education.

\section{Notes}

\footnotetext{
${ }^{1}$ Available at: https://eige.europa.eu/gender-mainstreaming/what-is-gender-mainstreaming

${ }^{2}$ Available at: https://eur-lex.europa.eu/legal-content/EN/TXT/?uri=COM\%3A2020\%3A152\%3AFIN
} 


\section{References}

Bem, S. (1993). The Lenses of Gender: Transforming the Debate on Sexual Inequality. Yale University Press.

CEDAW. (1979). Convention on the Elimination of All Forms of Discrimination against Women. https://www.ohchr.org/EN/ProfessionalInterest/Pages/CEDAW.aspx

EIGE. (2019). Gender Equality Index 2019: Still far from the finish line. https://eige.europa.eu/news/gender-equality-index-2019-still-far-finish-line

Carvalho-Pinto, V., \& Fleschenberg, A. (2019). As múltiplas inter-relações entre questões de género e a aquisição de status na arena internacional. ex aequo, 40, 9-14. https://doi.org/10.22355/exaequo.2019.40.01

Istanbul Convention. (2011). Council of Europe Convention on preventing and combating violence against women and domestic violence. https://www.coe.int/en/web/conventions/full-list//conventions/treaty/210

Merrill, B., \& Puigvert, L. (2001). Discounting other Women, in Researching Widening Access International Perspectives, Conference Proceedings, CRLL, Glasgow, Glasgow Caledonian University.

Ollagnier, E. (2014). Femmes et défis pour la formation des adultes. Un regard critique non-conformiste. Paris: L'Harmattan.

Ostrouch-Kamińska J., \& Vieira C. C. (2016). Gender sensitive adult education: Critical perspective. Revista Portuguesa de Pedagogia, 50(1), 37-56.

Platform of Beijing. (1995). Fourth World Conference on Women. Beijing Declaration and Platform for Action. https://www.un.org/womenwatch/daw/beijing/platform/

Skeggs, B. (1997). Formations of Class and Gender. London: Sage.

Smith, D. (1987). Women's Perspective as a Radical Critique of Sociology. In S. Harding, (Ed.), Feminism and Social Theory, (pp. 84-96). Milton Keynes, Open University Press.

Sustainable Development Goals. (2015). Transforming our world: the 2030 Agenda for Sustainable Development. https://sustainabledevelopment.un.org/post2015/transformingourworld

Ubieta, C, Henriques, F., \& Toldy, T. (2018). A ‘ideologia de género’ da Igreja Católica. ex aequo, 37, 917. https://doi.org/10.22355/exaequo.2018.37.01

Verloo, M. (2007). Multiple meanings of gender equality: a critical frame analysis of gender policies in Europe. Budapest: CEU Press.

Vieira, C. C. (2012). Gender dimensions in Portuguese academia: an erratic relationship between political intentions and curricula priorities. In J. Ostrouch-Kamińska, Ch. Fontanini, \& S. Gaynard (Eds.), Considering gender in adult learning and in academia: (in)visible act (pp. 79-87). Wrocław: Wydawnictwo Naukowe Dolnośląskiej Szkoły Wyższej. 